\title{
Ewa Wótkiewicz
}

\author{
Spiżarnia biskupa. \\ Konsumpcja na dworze biskupów wrocławskich \\ w świetle rachunków z 1449 i 1450 roku
}

\begin{abstract}
Abstrakt: Artykuł zawiera analizę rachunków z dworu legnickiego, centrum jednego z kluczy majątkowych biskupstwa wrocławskiego. Zachowane zapiski zawierają obszerne wykazy produktów dostarczonych na potrzeby biskupa Piotra Nowaka, podczas jego pięciu wizyt w Legnicy, między czerwcem 1449 r. a końcem kwietnia $1450 \mathrm{r}$. W rachunkach rysuje się wyraźna różnica między zwykłym trybem funkcjonowania dworu, a nadzwyczajnym okresem, gdy gości w nim jego właściciel. Zwraca uwagę przede wszystkim różnorodność produktów oraz dbałość, aby podczas każdej z wizyt podać inne, nieserwowane wcześniej specjały. Większość tych delikatesów kupowano w niewielkich ilościach, z przeznaczeniem dla wąskiego grona, być może tylko dla biskupa.

Abstract: This article analyses the accounts of the court of Legnica, the centre of one of the estates that belonged to the bishopric of Wrocław. The surviving records contain extensive lists of products supplied for Bishop Piotr Nowak during his five visits to Legnica, between June 1449 and the end of April 1450. The accounts reflect the clear difference between the ordinary functioning of the manor and the extraordinary period when the owner visited it. Attention is primarily drawn to the variety of products and the care taken to serve during each visit different delicacies, which had not been served to the Bishop during his previous stays. Most of these delicacies were bought in small quantities for a small group of people, perhaps only for the Bishop Nowak himself.
\end{abstract}

Słowa kluczowe: Śląsk, Legnica, historia konsumpcji żywnościowej, historia Kościoła, późne średniowiecze

Key words: Silesia, Legnica, food history, church history, late Middle Ages

Kuchnia elitarna i nawyki żywieniowe przedstawicieli uprzywilejowanych warstw społeczeństwa stanowią od dłuższego czasu przedmiot intensywnego zainteresowania historyków. Praktyki konsumpcyjne w tych środowiskach pełniły bowiem szersze niż tylko czysto alimentacyjne funkcje. Ich rekonstrukcja pozwala wyciągnąć wnioski o charakterze społecznym i kulturowym, w tym analizować kwestie manifestacji prestiżu, hierarchii oraz społecznej dystynkcji ${ }^{1}$.

W dotychczasowych badaniach niewiele uwagi poświęcono jednak kulinariom na dworach biskupich. Nadzwyczaj skromnie przedstawia się stan badań w przypadku wyższego kleru metropolii gnieźnieńskiej, dla którego cząstkowe studia dostępne są jedynie dla epoki nowożytnej². Badania nad biskupią konsumpcją w późnym średniowieczu utrudnia nieporównanie skromniejsza baza źródłowa dla tego okresu, w tym przede wszystkim ubóstwo przekazów o charakterze rachunkowym. $Z$ tego względu warto zwrócić uwagę na niewielki objętościowo,

\footnotetext{
${ }^{1}$ Przegląd nowszej literatury na ten temat: Kozák P. 2016, s. 63-64.

2 Kościelak S. 2012; Dygdała J. 1997.
} 
ale bardzo cenny z perspektywy informacyjnej, zachowany z lat 1449-1450 fragment rachunków jednego z kluczy majątkowych biskupstwa wrocławskiego. Zapiski te zawierają obszerne wykazy produktów dostarczonych na potrzeby biskupa Piotra Nowaka, podczas jego pięciu wizyt w Legnicy, do których doszło między czerwcem 1449 r. a kwietniem następnego roku.

Mimo iż posiadłości biskupów wrocławskich w Legnicy odnotowane zostały już w bulli Hadriana IV z 1155 r., to funkcjonowanie tam rezydencjalnego dworu biskupów wrocławskich poświadczone jest dopiero od połowy XIII w. Jego zabudowania zlokalizowane były na ulicy Panieńskiej (Frauengasse), przylegającej bezpośrednio do brzegu Młynówki wpadającej do Kaczawy $^{3}$. Wedle rekonstrukcji planu miasta z połowy XV w. kuria biskupia miała sąsiadować z plebanią kościoła Najświętszej Marii Panny oraz farbiarnią ${ }^{4}$. Z innych przekazów wiadomo, że w pobliżu mieściła się również łaźnia ${ }^{5}$. Tereny znajdujące się w posiadaniu biskupa położone były obok dawnej drogi biegnącej do Wrocławia oraz lokalnego targu. Legnicki dwór stanowił założenie pokaźnych rozmiarów, w którym znajdowała się odrębna biskupia kaplica pod wezwaniem św. Marii Magdaleny ${ }^{6}$. Samo jego usytuowanie było jednak dość niefortunne, gdyż ze względu na bliskość rzeki był on narażony na częste podtopienia. Rekonstrukcja średniowiecznego założenia jest utrudniona, gdyż w końcu XVII w. dokonano jego przebudowy i wzniesienia barokowego kompleksu wraz ze świątynią św. Jana Nepomucena, która zastąpiła dawną kaplicę. Podjęte w latach osiemdziesiątych XX w. badania archeologiczne nie przyniosły znaczących rezultatów, ponieważ ze względu na wysoki poziom wód gruntowych prace musiały zostać przerwane przed osiągnięciem poziomu warstw z okresu pełnego średniowiecza? Rezydencja była własnością biskupów wrocławskich do czasu sekularyzacji w $1810 \mathrm{r}$.

Dwór legnicki pełnił istotną rolę w systemie zarządu dóbr biskupich i administrowaniu diecezją. Był on jednym z pięciu ośrodków stanowiących centra kluczy majątkowych oprócz Wrocławia, Otmuchowa, Głogowa i Ujazdu ${ }^{8}$. We dworze rezydował biskupi prokurator, w którego gestii znajdował się nadzór nad dobrami zlokalizowanymi w okolicach Legnicy. Wykaz wsi należących do biskupstwa, dziesięcin oraz innych pożytków płynących do mensy biskupiej zawiera sporządzony w drugim dziesięcioleciu XIV w. Liber fundationis ${ }^{9}$. Akta z klucza legnickiego zachowały się szczątkowo, z wyjątkiem jednego z tomów rachunków z czasu zarządu prokuratora Michała Franke. Poszyt ma postać dutki składającej się z 24 papierowych kart. Pierwszy umieszczony w nim wpis dotyczy poniedziałku po niedzieli Jubilate 1449 r. (4 maja), a zapiski były prowadzone do 17 października $1450 \mathrm{r} .{ }^{10} \mathrm{~W}$ źródle znalazły się niemal wyłącznie wykazy wydatków finansowanych z kasy prokuratorii, co wskazuje, że musiała też być prowadzona odrębna dokumentacja przychodów. Wpisów dokonywano zarówno w języku łacińskim, jak i niemieckim, przy czym niejednokrotnie obu języków używano w jednej zapisce.

Spisujący wydatki Michał Franke objął swój urząd w drugiej połowie lat czterdziestych XV w., gdyż jeszcze w 1445 r. jako prokurator był wymieniany Jan Brawna ${ }^{11}$. Zmiana na urzędzie mogła być wynikiem wyboru nowego biskupa - Piotra Nowaka, który odbył uroczysty ingres do katedry w październiku 1447 r. Franke niewątpliwie sprawdził się na swoim stanowisku, które utrzymał także po śmierci Nowaka i objęciu biskupstwa przez Jodoka z Rožmber-

${ }^{3}$ Urkundenbuch. 1866, nr 501.

${ }^{4}$ Pudełko J. 1971, s. 258.

5 Urkundenbuch. 1866, nr 20, 94.

${ }^{6}$ Jujeczka S. 2006, s. 105.

7 Laszewski W. 2011.

8 Por.: Wółkiewicz E. 2010, s. 84-97.

9 Liber fundationis. 1899, s. 114-140.

${ }^{10}$ APWr, AmW, nr 358 (dalej cyt.: Reg. distr.).

11 Por.: Jujeczka S. 2006, s. 169. 
Tabela 1

Wydatki prokuratora legnickiego na utrzymanie dworu biskupiego w latach 1449-1450 (w groszach i denarach)

Table 1

The expenses of the Legnica procurator for the sustenance of the bishop's court in 1449-1450 (in groschen and denars)

\begin{tabular}{|c|c|c|c|c|c|c|c|c|}
\hline Lp. & Mięso & $\begin{array}{c}\text { Ryby } \\
\text { i raki }\end{array}$ & $\begin{array}{c}\text { Nabiał, jaja, } \\
\text { olej }\end{array}$ & $\begin{array}{c}\text { Warzywa } \\
\text { i owoce }\end{array}$ & Pieczywo & Napoje & Inne & Suma \\
\hline 1 & $168+10 \mathrm{~d}$ & 97 & $5+6 \mathrm{~d}$ & $9+6 \mathrm{~d}$ & 22 & $61+6 \mathrm{~d}$ & $117+9 \mathrm{~d}$ & $482+1 \mathrm{~d}$ \\
\hline 2 & $42+8 \mathrm{~d}$ & $134+8 \mathrm{~d}$ & 8 & 11 & 23 & $416+6 \mathrm{~d}$ & $106+6 \mathrm{~d}$ & $742+4 \mathrm{~d}$ \\
\hline 3 & $157+2 \mathrm{~d}$ & $50+2 \mathrm{~d}$ & 44 & $14+8 \mathrm{~d}$ & $10+6 \mathrm{~d}$ & 176 & $60+8 \mathrm{~d}$ & $513+2 \mathrm{~d}$ \\
\hline 4 & $516+6 \mathrm{~d}$ & $82+6 \mathrm{~d}$ & $25+6 \mathrm{~d}$ & 9 & 21 & 59 & $44+11 \mathrm{~d}$ & $758+5 \mathrm{~d}$ \\
\hline 5 & $274+4 \mathrm{~d}$ & 158 & $4+3 \mathrm{~d}$ & $12+6 \mathrm{~d}$ & 26 & $10+8 \mathrm{~d}$ & $156+9 \mathrm{~d}$ & $642+6 \mathrm{~d}$ \\
\hline Suma & $1159+6 \mathrm{~d}$ & $522+4 \mathrm{~d}$ & $87+3 \mathrm{~d}$ & $56+8 \mathrm{~d}$ & $102+6 \mathrm{~d}$ & $723+8 \mathrm{~d}$ & $486+7 \mathrm{~d}$ & $3138+6 \mathrm{~d}$ \\
\hline
\end{tabular}

Źródło: APWr, AmW, nr 358.

ka (1456-1467) ${ }^{12}$. Jako prokurator w Legnicy wzmiankowany jest przynajmniej do roku 1461, a jego następca znany jest dopiero z czasu pontyfikatu kolejnego biskupa - Rudolfa z Rüdesheim $(1468-1482)^{13}$.

W zachowanej księdze rachunkowej wyszczególniono kilka kategorii wydatków. Pierwszych dziewięć kart zajmują koszty utrzymania dworu w układzie chronologicznym, wypłaty na wyjazdy związane z poborem świadczeń należnych biskupowi oraz wynagrodzenie dla posłańców. Na kolejnych trzech kartach prokurator spisał analizowane tu wydatki z tytułu wizyt Piotra Nowaka. Ponieważ zostały one zarejestrowane osobno, nie zaś w podstawowym bloku zapisów, możliwe jest dość dokładne ustalenie rzeczywistych nakładów na konsumpcję ordynariusza i jego świty.

W rachunkach zostały odnotowane cztery pobyty biskupa w $1449 \mathrm{r}$. Pierwszy z nich rozpoczął się 11 czerwca, wkrótce jednak Nowak opuścił miasto i udał się do Głogowa. Dotarcie do tego miasta poświadcza dokument wystawiony 18 czerwca 1449 r. ${ }^{14}$ Następnie musiał przemieścić się do Żagania, gdyż autor rachunków pod 25 czerwca zapisał, że biskup przybył de Sagano ${ }^{15}$. W dworze legnickim zatrzymał się tym razem tylko przejazdem, zdążając do Wrocławia. Do stolicy diecezji wyruszył po krótkim popasie, już 28 czerwca $^{16}$. Kolejny pobyt Piotra Nowaka w Legnicy przypadł na sierpień. Wedle wpisu w księdze rachunkowej, biskup przybył 25 sierpnia, dwa dni później wystawił w mieście dokument ${ }^{17}$, natomiast 29 sierpnia był już we Wrocławiu, niewątpliwie w związku z obradami kapituły generalnej rozpoczynającej się w dniu Ścięcia św. Jana ${ }^{18}$. Po ok. dwutygodniowy pobycie w stolicy diecezji powrócił do Legnicy. Jego wizyta potwierdzona jest w dniach 13-17 września, natomiast już 19 dnia tegoż miesiąca wzmiankowana jest jego obecność we Wrocławiu ${ }^{19}$.

${ }^{12}$ APWr, DmW, (1461).

${ }_{13}$ AAW, II b 3, f. 40r.

${ }^{14}$ APWr, DmW, nr 3447.

${ }^{15}$ Reg. distr., f. 10v.

${ }_{16}$ Dotarcie biskupa do Wrocławiu poświadcza dyplom wystawiony z datą 1 lipca 1449 r., APWr, Rep. 116, nr 309 (zag.)

${ }_{17}$ APWr, DmW, nr 3463.

18 AAW, DC, 29 VIII 1449; Wykaz regestów. 1970, nr 1002.

19 Prokurator odnotował tylko dzień przybycia Nowaka: Sabbato ante Crucis venit dominus meus de sera de Wratislavia, Libr. distr., f. 12r. Dokument ugody z 17 IX potwierdza obecność biskupa w Legnicy, natomiast już wieczorem 19 IX przebywał we Wrocławiu, AAW, II b 2, f. 27r-27v. 
Piąta wizyta przypadła na kwiecień 1450 r. Biskup Nowak zjechał do dworu wieczorem w czwartek 16 kwietnia, a opuścił go rano we wtorek 21 kwietnia, kierując w stronę północnej części swojej diecezji ${ }^{20}$.

Z analizy itinerariów biskupów wrocławskich wynika, że dwór legnicki pełnił istotną funkcję w organizacji objazdów diecezji. Biskupi mieli tu wygodne miejsce postojowe, w którym mogli się zatrzymać w drodze z Wrocławia do Głogowa, skąd następnie przemieszczali się do dalej położonych miejscowości. Dobrze potwierdzają tę praktykę informacje o wizytach Nowaka w czerwcu 1449 r., podczas których dwór legnicki stanowił miejsce popasu zarówno w drodze do Głogowa i Żagania, jak i podczas powrotu stamtąd do stolicy diecezji. Także w kwietniu 1450 r. Legnica była jednym z przystanków na dłuższej trasie, choć w tym przypadku brak jednoznacznego potwierdzenia ponownego postoju w drodze powrotnej ${ }^{21}$. Wizyty w mieście nie zawsze jednak były wyłącznie etapem w dłuższej podróży wrocławskich ordynariuszy. Potrzeby przyjazdu mogły wynikać z licznych względów administracyjno-duszpasterskich, a także politycznych. Względna bliskość biskupiej rezydencji we Wrocławiu ułatwiała zaplanowanie i logistykę takiej wizyty. Aż cztery pobyty Piotra Nowaka w 1449 r. miały jednak charakter nadzwyczajny, gdyż wiązały się z przewodniczeniem sądowi rozjemczemu w konflikcie księcia głogowskiego-ścinawskiego Włodka i rajców wrocławskich. W czerwcu biskup zatrzymał się we dworze jedynie przejazdem, gdyż właściwe rozmowy toczyły się w Głogowie, natomiast już we wrześniu miejscem polubownych rokowań była sama Legnica. 17 września 1449 r. biskup uczestniczył w uroczystym zawarciu ugody między zwaśnionymi stronami ${ }^{22}$.

Analizę przedstawionych rachunków utrudnia fakt, że tylko w przypadku jednej z wizyt znany jest dokładny czas pobytu gości we dworze. W kwietniu 1450 r. biskup przybył wieczorem 16 kwietnie i odjechał rano 21 kwietnia, czyli spędził w siedzibie łącznie pięć nocy. Dla pozostałych pobytów dysponujemy jedynie przybliżonymi danymi, z których wynika jednak, że biskup nie decydował się na więcej niż pięć noclegów (pobyt pierwszy i czwarty), a w dwóch przypadkach został jedynie na trzy, bądź nawet na dwie noce (pobyt drugi i trzeci).

Tylko dla dwóch wizyt zachowane są informacje o liczebności biskupiego orszaku. We wrześniu 1449 r. prokurator legnicki odnotował, że świta ordynariusza miała liczyć 45 koni; podobną liczbę zarejestrował wiosną następnego roku - 44. Trudno jednak przesądzać, czy były to typowe rozmiary grupy towarzyszącej Piotrowi Nowakowi. Dla innych wizyt brak podobnych danych; w niewielkim stopniu pomocne są listy świadków z biskupich dokumentów, wymieniające tylko najważniejszych dostojników. Trzon dworu biskupa stanowili niewątpliwie kapelan, przełożony kancelarii, komornik, marszałek, a często także sędzia dworski ${ }^{23}$. Podczas pobytów Nowaka w 1449 i 1450 r. obecne były następujące osoby: kapelan Jakub Steyner ${ }^{24}$, kanclerz Benedykt Ottendorf ${ }^{25}$ oraz komornik Kacper Jonsdorf ${ }^{26}$. Biskupowi towarzyszył także prepozyt kapituły katedralnej Kacper Weigil, oraz tamtejsi kanonicy: dr decr. Henryk Czewchner, Henryk Eichilborn zwany Clodobok, Andrzej Skoda i Zygmunt Atze ${ }^{27}$. W grupie

2029 IV 1450 r. potwierdzona jest jego obecność w Kożuchowie, AAW, II b 2, f. 39r-39v.

${ }^{21}$ Dwukrotny popas w Legnicy jest jeszcze potwierdzony w 1451 r. Nowak nocował wówczas we dworze legnickim w końcu marca, następnie ruszył do Głogowa, Żagania i Kożuchowa, by w powrotnej drodze, w połowie kwietnia ponownie zatrzymać się w Legnicy, AAW, II b 2, f. 48r, 52r-52v.

22 APWr, DmW, nr 3479-3481.

23 Na temat otoczenia Piotra Nowaka szerzej w: Wółkiewicz E. 2012, s. 99-102. O organizacji dworu biskupów wrocławskich w XV w., por.: Wółkiewicz E. 2008.

${ }^{24}$ Biogram Steynera: Wółkiewicz E. 2004, nr 86.

25 Por.: Wółkiewicz E. 2012, s. 99.

26 Świadectwem obecności Jonsdorfa w Legnicy jest tylko wzmianka o wypłacie gotówki na jego rzecz, wpisana do księgi rachunkowej po wykazie wydatków związanych z wizytami biskupa, Reg. distr., f. 14r. Na temat Jonsdorfa, por:: Dola K. 1983, nr 73.

27 Sylwetki duchownych: Dola K. 1983, nr 1, 25, 32, 172, 207; Jujeczka S. 2006, nr 553. Atze — wzmiankowany w otoczeniu Nowaka w kwietniu 1450 r. był wówczas plebanem ząbkowickim, niemniej jeszcze w tym samym roku został przyjęty do grona kanoników katedralnych. 
świeckich ważne miejsce zajmował ówczesny marszałek Henryk Czeschwitz, który z racji swojego urzędu był odpowiedzialny za organizację biskupich podróży. Do eskorty należał ponadto Mikołaj Streit z Prusinowic, który ok. 1453 r. został następcą Czechwitza, a także Ulryk Monsterberg, marszałek poprzedniego biskupa Konrada oleśnickiego ${ }^{28}$. W świcie Nowaka znalazł się zapewne także jego cześnik - Zygmunt Duchowski. W rachunkach prokuratora legnickiego umieszczona jest również adnotacja o wynagrodzeniu dla kuchmistrza, którego imię nie jest znane ${ }^{29}$. Dalszymi osobami należącymi do dworu Nowaka był jeden z wasali z władztwa otmuchowsko-nyskiego - Henryk von Kusmalcz ${ }^{30}$ oraz niejaki Scholczychen ${ }^{31}$. Wymieniona przez prokuratora liczba członków biskupiej świty z pewnością nie odpowiadała rzeczywistej liczbie stołowników we dworze. Niewątpliwie obecni byli bowiem dodatkowi goście zapraszani przez biskupa, w tym przede wszystkim członkowie kapituły legnickiej, z którymi Piotr Nowak dowodnie się spotykał. Duchowni ci uczestniczyli w akcjach prawnych we dworze, a niektórzy towarzyszyli ordynariuszowi w kolejnych etapach podróży ${ }^{32}$.

Zachowany rejestr wydatków dworu umożliwia wejrzenie w materialny aspekt pobytów biskupa w Legnicy, w tym w kwestię konsumpcji żywnościowej. Podstawowym wyznacznikiem elitarności kuchni okresu przednowoczesnego była bez wątpienia obfitość potraw mięsnych. Rachunki legnickiej siedziby w pełni potwierdzają dotychczasowe obserwacje badaczy. Koszty zakupu mięsa miały największy udział w ogólnej puli wydatków związanej z pobytami Piotra Nowaka. Łącznie wydano na ten cel ponad 24 grzywny (ok. 37\%). Bardzo wyraźna jest też praktyka wyboru różnorodnych gatunków mięs i dbałość o urozmaicenie posiłków. Znaczny udział w jadłospisie miała wołowina. To do jej zakupów odnoszą się niewątpliwie zapisy o nabywaniu ,ćwierci” mięsa (eyn firtel fleysch), gdyż był to typowy sposób sprzedaży tego rodzaju mięsa (wieprzowinę oferowano zwykle w połciach). Cena jednej ,ćwierci” była zależna od jej wielkości i wahała się od 17 do 34 gr. Wołowinę zapewniano jednak przede wszystkim poprzez zakup całych zwierząt. I tak, we wrześniu 1449 r. prokurator sprowadził trzy woły z Głogowa, płacąc za każdego dwie grzywny i jeden wiardunek, a niewiele mniej kosztowało go zwierzę kupione wiosną następnego roku ${ }^{33}$. Na stół biskupi często trafiały też cielęta. Nabywano je zarówno w całości, jak w częściach, podczas niemal wszystkich pobytów ordynariusza. $\mathrm{W}$ jednym przypadku upieczono też osobno cielę pro via, tj. w ramach aprowizacji w podróży ${ }^{34}$. Potrawy z młodych zwierząt stanowią wyróżnik kuchni elitarnej. Do kategorii tej można doliczyć zakup jagnięciny za 4 gr. ${ }^{35}$ Biskupowi zaserwowano również prosięta, których trzy sztuki prokurator kupił za 12 gr. Baranina i wieprzowina pełniły przy tym raczej marginalną rolę w wyżywieniu biskupiego dworu. W rachunkach odnotowano zakup tylko czterech baranów, a z kolei całych wieprzy nie kupowano wcale, jedynie dwukrotnie nabyto pieczeń

${ }^{28}$ Ulryk Monsterberg jest wielokrotnie wymieniany w grupie osób towarzyszącej Piotrowi Nowakowi w podróżach. Nie ma jednoznacznego potwierdzenia jego obecności w Legnicy, ale na pewno był w Kożuchowie, dokąd biskup udał się z Legnicy w drugiej połowie kwietnia 1450 r., AAW, II b 2, f. 39v-40r.

${ }^{29} \mathrm{Na}$ dworze Konrada funkcję kuchmistrza pełnił Mikołaj Dzalusz zwany Mymo (np. AAW, III d 1a, f. 219r). Ten ostatni poświadczony jest także w otoczeniu biskupa Nowaka (por.: AAW, II b 2, f. 38r-39v), niemniej brak dowodów, by nadal był biskupim kuchmistrzem.

${ }^{30}$ Henryk von Kusmalcz został wymieniony wśród świadków ugody zawartej w Legnicy 17 IX 1449 r. (APWr, DmW, nr 3479). Kilkukrotnie towarzyszył także biskupowi podczas objazdów diecezji (np. AAW, II b 2 , f. $66 \mathrm{v}-67 \mathrm{r}$ )

31 Por. Reg. distr., f. 10v.

32 Np. świadkami dyspozycji biskupa z 13 VI 1449 r. było trzech prałatów legnickich: prepozyt Jan Bawde, dziekan Jan Girdan oraz kustosz Prokop (AAW, II b 2, 26v-27r). Jan Bawde udał się następnie razem z biskupem do Głogowa.

33 Reg. distr., f. $12 \mathrm{v}$.

34 Reg. distr., f. $13 \mathrm{v}$.

35 Reg. distr., f. 10v. 
wieprzową ${ }^{36}$. Warto natomiast zwrócić uwagę na mało typową pozycję w średniowiecznym menu, jakim była kozina ${ }^{37}$. Ten rzadko spotykany produkt pojawił w rachunkach legnickiego prokuratora w kwietniu 1450 r., gdy sprowadzono łącznie sześć kóz ${ }^{38}$ Trudno jednak przesądzać, czy zakupy te były podyktowane chęcią urozmaicenia biskupiej diety, czy też były spowodowane pobytem liczniejszej świty, dla której mogły być przeznaczone owe zwierzęta. Podobne wątpliwości budzą wyszczególnione w rachunkach dwa rodzaje podrobów: flaki (3 gr) oraz faszerowany barani żołądek (18 gr). Ta ostatnia potrawa cieszyła się w tym czasie dużą popularnością na Śląsku i kupowano ją także w innych okresach roku dla personelu dworu legnickiego ${ }^{39}$. Mimo iż w większości podroby nie były w tym okresie szczególnie cenione, niektóre z nich należały jednak do ekskluzywnego menu. Do takich wyjątków zaliczała się przede wszystkim cielęca grasica i cielęca głowa ${ }^{40}$. Potwierdzone jest także kupowanie flaków dla wysoko postawionych osób ${ }^{41}$.

Podstawowym gatunkiem mięsa w kuchni elitarnej był niewątpliwie drób. Na stół biskupi trafiał szeroki wybór zarówno ptactwa domowego, jak i dzikiego. W rachunkach rozróżniane są „stare kury” (alde henne) oraz „młode kury” (junge henne) oraz osobno specjalnie tuczone kurczaki (pulli). Potrawy z kur były stałym elementem menu i podczas wszystkich wizyt Piotra Nowaka prokurator dokonywał ich zakupów na rynku. W sierpniu i wrześniu 1449 r. do tego podstawowego zestawu dołączono też kaczki. W rachunkach wymieniane są dwa ich rodzaje - domowe i dzikie (antfogel) ${ }^{42}$. Szczególny charakter pobytu wrześniowego, związanego z zawarciem ugody między radą Wrocławia a księciem głogowskim, znalazł odzwierciedlenie w bardziej uroczystym jadłospisie, w którym uwzględniono liczne dzikie ptactwo. Zakupiono wówczas blisko 500 sztuk różnych ptaków. Wśród odnotowanych gatunków były: zięby

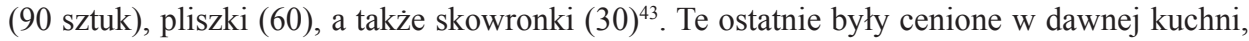
a jak twierdził osiemnastowieczny przyrodnik, Remigiusz Ładowski „naylepsze są na stół osobliwie wiosną, gdyż mięso ich smaczne i tłuste" 44 . Z większych ptaków na stół biskupa przeznaczony był batalion ${ }^{45}$ oraz kulik (brochvogel) ${ }^{46}$.

Przegląd zakupów prokuratora legnickiego świadczy, że — zgodnie z typową dla późnego średniowiecza i wczesnej nowożytności praktyką - kupowano zarówno poćwiartowane mięso, jak i całe zwierzęta. Znacznie chętniej decydowano się przy tym na ten drugi wariant, zapewne sprawiając zwierzęta we własnym zakresie. Także drób kupowano żywy, o czym świadczą zarejestrowane osobno wydatki na jego karmę ${ }^{47}$. Taki proceder pozwalał nie tylko na lepszą kontrolę świeżości mięsa, ale i na jego odpowiednie utuczenie ${ }^{48}$.

Podczas pobytu biskupa inny charakter niż w pozostałych częściach roku miały także zakupy ryb. W rachunkach rzadko wzmiankowane są wówczas niesprecyzowane bliżej pod względem

36 Reg. distr., f. $11 \mathrm{v}-12 \mathrm{v}$.

37 Por.: Dembińska M. 1963, s. 99. Mięso kozie nie było uwzględniane w średniowiecznych książkach kucharskich (por:. Rabeler S. 2000, s. 121-122). Tylko sporadycznie wymieniane jest w późnośredniowiecznych rachunkach (np.: Zíbrt Č. 1927, s. 105).

38 W kwietniu 1450 r. prokurator zakupił łącznie 6 kóz, płacąc 28 groszy. Cena jednej sztuki wahała się od 4 do 5,5 gr, Reg. distr., f. 13r-13v.

39 Reg. distr., f. 3r, 6r, 7r. Na południu Niemiec w późnym średniowieczu popularna była pokrewna potrawa zwana Saumagen. Jej przyrządzenie polegało na faszerowaniu wieprzowego żołądka masą z rozdrobnionego mięsa i warzyw, a po wstępnym obgotowaniu, na wyjęciu farszu i pokrojeniu go w plastry, które następnie jeszcze przysmażano, por.: Kleinschmidt W. 2012, s. 72-73; Stadtkölnische Reiserechnungen. 2007, s. XXXVII.

40 Kleinschmidt W. 2012, s. 106.

41 Np.: Hirsch V. 2002, s. 172; Strauss F. 1987, s. 590.

42 Reg. distr., f. 11v.

${ }^{43}$ Reg. distr., f. 12r-12v.

44 Por. Samsonowicz A. 1991, s. 137.

45 Reg. distr., f. 12r.

46 Reg. distr., f. 13r.

47 Reg. distr., f. 11r.

48 Por.: Karbowiak A. 1900, s. 16-17. 
Tabela 2

Ceny wybranych produktów żywnościowych z rachunków dworu biskupiego w Legnicy na przełomie 1449 i $1450 \mathrm{r}$.

Table 2

Prices of selected food products from the accounts of the bishop's court in Legnica at the turn of 1450

\begin{tabular}{|c|c|c|c|}
\hline Lp. & Produkt & Ilość & $\begin{array}{c}\text { Cena } \\
\text { (w groszach i denarach) }\end{array}$ \\
\hline 1 & mięso wołowe & ćwierć & $17-34$ \\
\hline 2 & wół & sztuka & 100 \\
\hline 3 & cielę & sztuka & $9-26$ \\
\hline 4 & baran & sztuka & $12-16$ \\
\hline 5 & prosię & sztuka & 4 \\
\hline 6 & koza & sztuka & $4-5,5$ \\
\hline 7 & żołądek barani & sztuka & $6-18$ \\
\hline 8 & kura & sztuka & $5 d-16 d$ \\
\hline 9 & kaczka & sztuka & $1-1+4 d$ \\
\hline 10 & kulik & sztuka & $7 \mathrm{~d}$ \\
\hline 11. & skowronki & pół kopy & 2,5 \\
\hline 12 & pliszki & kopa & $3+4 d$ \\
\hline 13 & leszcz & kopa & 11 \\
\hline 14 & certa & sztuka & $11 \mathrm{~d}$ \\
\hline 15 & karp & sztuka & $1,5-2,5$ \\
\hline 16 & Grundeln & garniec & $4-5$ \\
\hline 17 & olej & funt & $1+10 d-2$ \\
\hline 18 & jaja & kopa & $3-4$ \\
\hline 19 & masło & garniec & $5,5-10$ \\
\hline 20 & cebula & ćwierć korca & $1+8 d-3$ \\
\hline 21 & gruszki & ćwierć korca & 4,5 \\
\hline 22 & jabłka & ćwierć korca & 4 \\
\hline 23 & sól & ćwierć korca & $7,5-12$ \\
\hline 24 & piwo legnickie & wiertel & 46 \\
\hline 25 & piwo wrocławskie & wiertel & $48-51$ \\
\hline 26 & wino węgierskie & garniec & $6+8 d$ \\
\hline
\end{tabular}

Źródło: APWr, AmW, nr 358.

ilości i rodzaju pisces, natomiast prokurator skrupulatnie rejestruje cenione gatunki kupowane na sztuki. Do najczęściej serwowanych należały szczupaki, chętnie też przyrządzano karpie oraz inny gatunek ryby z rodziny karpiowatych - certę. Podczas wizyt w czerwcu 1449 r. sprowadzono z kolei sandacze oraz pięć kop halpfisch ${ }^{49}$, natomiast we wrześniu menu uzupełniły okonie i karasie. Specjalnym produktem, przeznaczonym na stół biskupi, były niewielkie ryby określane

${ }^{49}$ Reg. distr., f. 10r. Termin halbfisch stosowano zwykle na określenie różnego rodzaju ryb z gatunku płastug. Na Śląsku konsumowano jednak przede wszystkim ryby słodkowodne, stąd należy sądzić, że wspomniana zapiska odnosi się do regionalnej nazwy leszcza, por. Witkowski A., Żerelik R. 2001, s. 170. 
jako grundeln, kupowane na garnce i przyrządzane z dodatkiem wina, którego zakup do tego celu został osobno odnotowany ${ }^{50}$. Sporadycznie zaopatrywano się też w raki, które nabyto trzykrotnie w czerwcu 1449 r. ${ }^{51}$ Co symptomatyczne, w rachunkach ani razu nie pojawiły się śledzie, najpopularniejsza ryba spożywana w późnym średniowieczu w miastach środkowoeuropejskich. Śledzie uznawane były jednak za jedzenie pospolite, niestosowne dla osób o wyższej pozycji społecznej. Dystynkcję tę dobrze obrazuje ordynacja biskupa Spiry Mathiasa von Rammunga (1464-1478), w której jednoznacznie zakazano ich serwowania na stół biskupi ${ }^{52}$. W Legnicy wydatki na ryby i raki wyniosły łącznie ok. 12 grzywien (17\%).

Na tle całej puli wydatków stosunkowo niewielkie wydają się koszty pozyskiwania nabiału. Dwie odnotowane pozycje dotyczyły zakupów niewątpliwie o charakterze luksusowym. Stół biskupi został bowiem zaopatrzony w wyszukany rodzaj sera (weichekese), a także w świeże masł $^{53}$. To ostatnie miało wyższą cenę od powszechnie dostępnego masła solonego. Z tłuszczy roślinnych kucharz używał tylko bliżej nieokreślonego oleju. Podczas pobytów ordynariusza nabywano go w ilości 3-4 funtów ${ }^{54}$. W większej liczbie spożywano jaja. W analizowanym okresie nabyto ich łącznie 12 kop za sumę $40 \mathrm{gr}^{55}$.

W związku z przygotowaniem potraw dla biskupa znacznie zwiększyły się, zarówno pod względem ilościowym, jak i jakościowym, wydatki na warzywa i owoce. Więcej niż w innych miesiącach kupowano pospolitych warzyw, takich jak marchew, rzepa, cebula, pietruszka i kapu$\mathrm{sta}^{56}$. Natomiast warto zwrócić uwagę na rzadsze produkty, tj. szalotkę (aschlach) ${ }^{57}$ lub rzeżuchę $\left(k_{r e s s i n}\right)^{58}$. Dbano także o zaopatrzenie stołu biskupiego w sezonowe jarzyny, np. pod koniec czerwca prokurator nabył młody groch w strąkach ${ }^{59}$. Dietę uzupełniały owoce, nieuwzględniane w zwyczajnym jadłospisie załogi dworu (jabłka, gruszki, orzechy, a także winogrona) ${ }^{60}$. W czerwcu za 1 grosz kupiono ertber, czyli poziomki ${ }^{61}$. Dodatkowe koszty pochłonęły zakupy luksusowych dodatków do dań, tzn. ryżu, fig, rodzynek i cukru. Ten ostatni prokurator nabywał w niewielkich ilościach u miejscowego aptekarza (łącznie $30 \mathrm{gr})^{62}$. Zaskakujący jest natomiast brak przypraw typowych dla kuchni w późnym średniowieczu, czyli pieprzu, szafranu, imbiru, cynamonu, kwiatu i gałki muszkatołowej. Nie można wykluczyć, że kucharz korzystał z posiadanych zapasów korzeni. Na początku maja 1449 r. prokurator zrobił większe sprawunki, nabywając szafran, pieprz i imbir za ponad 2 grzywny srebra ${ }^{63}$. Bardziej prawdopodobne wydaje się jednak, że — podobnie jak w przypadku innych dworów biskupich — przyprawy woził ze sobą osobisty kucharz ordy-

50 Grundeln to dość ogólna nazwa niewielkich, przydennych ryb, przede wszystkim tych z rzędu karpiokształtnych i karpieńcokształtnych (por.: Liber ordinis rerum. 1983, s. 319). W Czechach i w południowych Niemczech zwykle odnosiła się do ślizu (niem. Schmerle, Bartgrundel), w innych rejonach okreslano w ten sposób kiełbie (niem. Gründling). W zachowanych książkach kucharskich z terenu środkowej Europy brak przepisu na przyrządzanie ich w winie, poświadczony jest natomiast sposób na podanie w galarecie (por.: Kochbuch. 1958, nr 47, s. 40). O popularności grundeln w tym okresie świadczą także wzmianki w innych zespołach rachunkowych (np.: Stadtkölnische Reiserechnungen. 2007, s. XXXVIII).

51 Reg. distr., f. 10r-10v.

${ }^{52}$ Fouquet G. 1988, s. 19.

53 Reg. distr., f. 13r-13v.

54 Reg. distr., f. 10v.

55 Reg. distr., f. 11v, 12v.

56 Reg. distr., f. $11 \mathrm{v}$.

57 Reg. distr., f. 10r.

58 Reg. distr., f. 12v.

59 Reg. distr., f. 10v. Młody groch był podawany jako jedno z dań deseru, por.: Karbowiak A. 1900, s. 19.

60 Reg. distr., f. 11v.

61 Reg. distr., f. 10r.

${ }^{62}$ Reg. distr., f. $13 r$.

63 Reg. distr., f. $1 \mathrm{r}$. 
nariusza, który wydzielał je następnie personelowi miejscowej kuchni. Analogii dostarczają w tym względzie obszerne materiały rachunkowe biskupa bazylejskiego Johanna von Venningen, w których również brak tej pozycji wśród zakupów w konkretnych rezydencjach ${ }^{64}$. W związku z pobytami biskupa w dworze legnickim uzupełniano natomiast zasoby soli. W czerwcu i sierpniu $1449 \mathrm{r}$. nabyto po ćwierć korca soli, natomiast w trakcie dwóch kolejnych wizyt zapotrzebowanie wzrosło do połowy korca. Łączne wydatki na ten produkt sięgnęły 1 grzywny i 16 gr.

Na potrzeby ordynariusza dostarczane było także białe pieczywo. W trakcie poszczególnych wizyt na bułki wydawano od 9 do $14 \mathrm{gr}^{65}$. W rachunkach nie ma natomiast żadnych wzmianek o kupnie chleba. Pod koniec każdego pobytu prokurator opłacał jednak usługę zwaną packlon (backlon?), która najpewniej dotyczyła płatności za wypiek pieczywa (10-12 gr).

Podstawowym napojem konsumowanym na dworze biskupim było piwo. Podczas każdej z wizyt Piotra Nowaka odnotowanych w 1449 r. kupowano wiertel tego napoju. W dwóch przypadkach zaznaczono, że było to piwo wrocławskie, za które uiszczono 48-51 gr oraz dodatkowe opłaty za transport (6-8 gr). Podobną kwotę zapłacono podczas pierwszego z pobytów, gdy również najpewniej sprowadzono towar $z$ Wrocławia $(50 \mathrm{gr}+8 \mathrm{gr})^{66}$. Legnicki trunek był tańszy i nie wymagał wynagrodzenia dla furmana, a koszty jego zakupu zamykały się w kwocie 46 gr i 1 gr z tytułu szrotu ${ }^{67}$. Biskup jednak niewątpliwie preferował droższy, zamiejscowy gatunek, cieszący się znaczną sławą także poza granicami Śląska ${ }^{68}$. W rachunkach wizyty z czerwca 1449 r. znalazły się także koszty zlecenia uwarzenia piwa w browarze. Prokurator wyszczególnił wydatki na zakup słodu (4,5 grzywny), chmielu (20 gr), opłatę dla miasta (12 gr), dla browaru (5 gr) oraz na wynagrodzenie dla warzących (11 gr), woziwody (2,5 gr), tragarzy (6 gr), wartherynne ( 3 gr), pro pice (6 gr), a także dla osób zakładających szpunty na beczki (31 gr ${ }^{69}$. Łącznie opłaty te wyniosły ok. 6,5 grzywny, niemniej samodzielne warzenie pozwalało uzyskać znacznie większą ilość trunku. Zamawianie piwa w browarze było stałą praktyką we dworze legnickim, jednak trudno wytłumaczyć, dlaczego zdecydowano się na nią w związku z przyjazdem biskupa. Czas potrzebny na przeprowadzenie całego cyklu produkcyjnego był dłuższy niż którykolwiek z jego pobytów. Jedynym możliwym wyjaśnieniem wydaje się wcześniejsze rozpoczęcie prac, po otrzymaniu informacji o planowanej wizycie. W opisanym przypadku biskup wyruszył w stronę Głogowa i Żagania i niewątpliwie uzgodnił swój ponowny popas w powrotnej drodze. Z kolei podczas wizyty w kwietniu 1450 r. wydatki na piwo były jedynie symboliczne (7 gr), co pozwala przypuszczać, że korzystano z zasobów uwarzonych we dworze miesiąc wcześniej ${ }^{70}$.

Znacznie skromniejsze były zakupy wina; podczas dwóch wizyt, wyłącznie jako dodatek do przygotowania ryb ${ }^{71}$. Jedynie w sierpniu 1449 r. serwowano je obok piwa. Prokurator nabył wówczas 18 garncy wina węgierskiego, płacąc za nie 2,5 grzywny (jeden garniec za 6 gr i 8 d), a ponadto jeden garniec pośledniejszego gatunku w cenie $2 \mathrm{gr}^{72}$.

${ }^{64}$ Hirsch V. 2002, s. 275-276; por. także: Kozák P. 2016, s. 79.

${ }_{65}$ Reg. distr., f. 10v, 11r, 12v, $13 \mathrm{v}$.

${ }^{66}$ Reg. distr., f. 10r, 12r, 12v.

67 Reg. distr., f. 11r.

68 Sława wrocławskiego pszenicznego piwa zwanego szeps (Der Breslauer Schöps) jest dobrze poświadczona w źródłach XVI w., por.: Okólska H. 2002, s. 51.

${ }^{69}$ Reg. distr., f. 11r. Wymieniona w tym zapisie wartherynne była zapewne zatrudniania do dozorowania etapu chmielenia piwa. W innym zestawieniu kosztów produkcji piwa pojawia się sackhelder, a więc dosłownie „trzymający worek”, czyli w tym kontekście niewątpliwie lnianą torbę, w której umieszczano chmiel w podgrzewanej brzeczce, por.: Karst D. 2002, s. 14-15. Na temat procesu warzenia piwa w epoce przednowoczesnej szerzej np.: Klonder A. 1983, s. 46-60; Dryja S. 2008, s. 185-208.

${ }^{70}$ Reg. distr., f. 4v.

${ }^{71}$ Reg. distr., f. 10r, 13v.

72 Reg. distr., f. 12 r. 
Rachunki legnickie rejestrują nie tylko sumy przeznaczone na obsługę biskupiego stołu, ale też koszty oporządzenia koni i wozów oraz prace związane z bardziej komfortowym wyposażeniem wnętrz mieszkalnych. Przybycie dużego konnego orszaku stanowiło dla personelu dworu legnickiego wyzwanie - konieczność szybkiego zgromadzenia odpowiedniej ilości paszy. Po pomoc zwracano się do gminy legnickiej, która dostarczała siana, za co prokurator odwdzięczał się napiwkiem dla miejskiego masztalerza ${ }^{73}$. Z kolei z klasztoru kartuzów udało się pozyskano zapas owsa ${ }^{74}$. Kolejnym obowiązkiem służb dworskich było zapewnienie usług kowala, który sprawdzał podkucie koni i stan wozów. Opłaty za jego usługi wzmiankowane są podczas każdej z wizyt i dotyczyły przede wszystkim mocowania podków. Koszt założenia jednej podkowy wynosił stosunkowo niewiele (ok. 10 denarów), jednak ze względu na ich liczbę (nawet ponad 50 sztuk), jednorazowe wydatki kształtowały się ok. 0,5-1 grzywny. Skromny udział w ogólnej puli miał natomiast serwis wozów, np. podczas wizyty w kwietniu $1450 \mathrm{r}$. wzmiankowano wydanie na ten cel tylko $2 \mathrm{gr}^{75}$.

Nagłe przybycie większej liczby osób powodowało także konieczność zwiększenia asortymentu i liczby sprzętów kuchennych oraz nakryć stołowych. Dwa razy kupiono po 60 łyżek ${ }^{76}$, dwukrotnie też uzupełniono zasoby garnków, dzbanów, kubków i moździerzy ${ }^{77}$. W rachunkach zawarte są też ekspensy jednoznacznie wskazujące na dbałość o komfort ordynariusza. Podczas pierwszego pobytu (w czerwcu 1449 r.) zarejestrowano wydatki w związku z przygotowaniem jego posłania bądź siedziska (von meines herrn pfule zcumachen). Z doraźnym aranżowaniem wnętrz można też wiązać pozycję z kwietnia 1450 r.: ,,papier do okien"'78.

Na potrzeby biskupa sprowadzono także lutnistów (3 gr), usługa ta poświadczona jest tylko jeden $\mathrm{raz}^{79}$. Natomiast większe koszty generowała praca kurierów posyłanych do Otmuchowa oraz Chojnowa i Okmianów ${ }^{80}$. Dodatkowe obciążenie spowodowały dwie biesiady totumfackich biskupa w miejscowej gospodzie, prowadzonej przez niejakiego Wechtera. Prokurator legnicki musiał najpierw uregulować rachunek za kanonika Henryka Clodoboka (6 gr), a następnie za trzech innych członków świty Piotra Nowaka (25 gr $)^{81}$. Z dochodów dworu legnickiego wypłacono także jałmużny rozdzielone przez biskupa ${ }^{82}$.

Łączne wydatki zarządcy dworu wyniosły ok. 65 grzywien, co pozwala w dużym przybliżeniu wyliczyć koszty zakupów na jedną dobę na ok. 3 grzywny. Przedstawione zestawienie niewątpliwie nie obejmuje wszystkich kwot związanych z wizytami kościelnego dostojnika w Legnicy. Wynika to jednak z samej specyfiki wykorzystanego źródła rachunkowego. W materiałach tego rodzaju zwykle rejestrowane są jedynie zakupy dokonywane na rynku, natomiast nie są uwzględniane wcześniejsze zapasy i zbiory z własnego gospodarstwa. Całkowity brak podstawowych produktów, jak chociażby mąka oraz kasze wskazuje, że musiano korzystać z własnych zasobów. Z tych samych powodów trudno szacować rzeczywistą konsumpcję warzyw, nabiału i jaj, które również można było pozyskać we własnym zakresie. Nieuniknione ograniczenia i niedostatki źródeł rachunkowych nakazują zachowanie dużej ostrożności i powstrzymanie się od pochopnych

${ }^{73}$ Reg. distr., f. 10r, 12v.

74 Reg. distr., f. 10r.

75 Podczas pierwszej wizyty kowalowi zapłacono blisko 50 gr za założenie 52 podków oraz pewne prace przy wozach. Podczas drugiego pobytu koszty te wyniosły 15 gr, a kolejnych — 36 gr i 8 d (za 18 podków), 30 gr (26 podków) i 19 gr (21 podków i serwis wozów).

${ }^{76}$ Reg. distr., f. 10r.

77 Reg. distr., f. 10v, 13r.

78 Reg. distr., f. 13r.

79 Reg. distr., f. 10r.

${ }^{80}$ Reg. distr., f. 10r.

81 Reg. distr., f. 10v.

82 Reg. distr., f. 11v, 13r. 
wniosków przy analizie materiału, w tym zwłaszcza przy interpretacjach braku pewnych produktów. Wymownym przykładem jest tu kwestia konsumpcji dziczyzny w kuchni elitarnej. Niektórzy badacze, nie znajdując jej w materiałach rachunkowych, skłonni byli przypuszczać, że odgrywała znikomą rolę w diecie w późnym średniowieczu. W dyskusji jednak słusznie wskazano, że dziczyzna była specyficznym artykułem, pozyskiwanym przede wszystkim drogą polowań lub darów, natomiast tylko $\mathrm{w}$ niewielkim zakresie handlowano nią na rynku ${ }^{83}$. Biskupom wrocławskim dziczyznę dostarczały służby leśne z ich władztwa, a w korespondencji z XVI w. jest poświadczenie, że wysyłali ją oni jako luksusowy prezent. $\mathrm{Z}$ ich dworem legnickim nie był połączony żaden kompleks leśny, nie można było zatem liczyć na uzupełnienie jadłospisu z tego źródła. Nie można jednak wykluczyć, że biskup otrzymał dziczyznę w formie podarunków.

Mimo wskazanej niedoskonałości źródeł rachunkowych umożliwiają one wgląd w nawyki żywieniowe biskupa i funkcjonowanie jego dworu. Z zapisek prokuratora legnickiego wyłania się obraz nadzwyczajnych okoliczności i znacznej mobilizacji nielicznego, podległego mu personelu. Przyjazd dużej grupy ludzi wymagał nie tylko dodatkowych zakupów żywności, ale też zastawy stołowej i sprzętów kuchennych, a także troski o wyżywienie i oporządzenie koni. Do obowiązków prokuratora należało również zapewnienie prowiantu na drogę. Nie wszystkie potrzebne produkty były dostępne na miejscowym rynku, skoro zwracano się o pomoc do władz miejskich i konwentu kartuzów. Niektóre towary sprowadzano spoza Legnicy, choć akurat w tym przypadku istotniejsza mogła być chęć dokonania korzystniejszego zakupu, jak w przypadku trzech wołów, które wybrano podczas jarmarku w Głogowie. Trudno jednakże wyjaśnić, dlaczego kury nabywano od zarządcy parafii w Jaworze odległym o $20 \mathrm{~km}$. Być może znaczące były tu inne, nierozpoznawalne obecnie względy.

W rachunkach rysuje się radykalna różnica między zwykłym trybem funkcjonowania dworu, a nadzwyczajnym okresem, gdy gości w nim jego właściciel. Lapidarnie ujął to Volker Hirsch badający majątki bazylejskiego ordynariusza Johannesa von Venningen: „Przyjazd biskupa to nie tylko zwiększenie ilości jedzenia, ale i zasadnicza jakościowa zmiana" "84. Rachunki legnickie ukazują niezwykle monotonne wyżywienie miejscowej załogi, dla której na rynku kupuje się głównie bliżej nieokreślane ryby i mięso (pro piscibus, pro carnibus). Jednostajność tę przerywają tylko nieliczne, specjalne sprawunki na święta (np. strucle z okazji Bożego Narodzenia). Incydentalnie nabywano rzadsze gatunki mięsa (zając, gęsi), przeznaczone albo dla samego prokuratora, albo dla nocujących we dworze członków biskupiego otoczenia ${ }^{85}$. Jak zostało to wykazane powyżej, odmiennie przedstawia się struktura wydatków w momencie przyjazdu do Legnicy Piotra Nowaka. Zwraca uwagę przede wszystkim wyjątkowa różnorodność produktów oraz dbałość, aby za każdym przyjazdem podać inne, nieserwowane wcześniej specjały. Większość tych delikatesów kupowano w niewielkich ilościach, dla wąskiego grona konsumentów, być może tylko dla biskupa. Bardzo wstrzemięźliwie — na tle chociażby dworu jagiellońskiego - przedstawia się na pewno konsumpcja napojów alkoholowych. W wyborze trunków widoczne są niewątpliwe elementy stanowej dystynkcji. Sprowadzane na stół biskupi piwo wrocławskie nie było kupowane w innych okresach roku, a podstawowym napitkiem dla załogi były poślednie gatunki, takie jak trebir oraz lankwala, albo wręcz podpiwek (potus). Do elitarnych trunków na pewno należał kupiony w sierpniu węgrzyn. Oprócz tego poświadczone są także opłaty za tańsze, miejscowe piwa, bądź wyrób piwa z własnych składników. Taka względna powściągliwość mogła być spowodowana kilkoma czynnikami.

${ }^{83}$ Por.: Kuropatnicki A. 2012, s. 224; Sperka J. 2012, s. 64-65.

${ }^{84}$ Hirsch V. 2004, s. 275.

${ }^{85}$ Reg. distr., f. 3 r. 
Piotr Nowak, obejmując rządy w diecezji wrocławskiej, zastał niezwykle trudną sytuację gospodarczą. Znaczna część majątków biskupstwa była wówczas zastawiona i przez cały okres swojego pontyfikatu był zmuszony inwestować większość dochodów w ich wykup ${ }^{86}$. Na dość oszczędną konsumpcję mogły też mieć wpływ indywidualne cechy osobowości biskupa, którego współczesny mu Jan Długosz charakteryzował: Vir frugi, humilis, prudens, industrius ${ }^{87}$. Trzeba podkreślić, że Nowak, w przeciwieństwie do swoich poprzedników i następcy, nie wywodził się z rodu książęcego ani z arystokracji, lecz wychował się w skromnym domu drobnej, lennej szlachty. Jego następca Jodok z Rožmberka nie cechował się już podobnym umiarem w wydatkach na żywność, np. kilka tysięcy grzywien przeznaczył tylko na zakup cukru.

Z tych względów otwarte pozostaje pytanie, na ile rachunki Nowaka są reprezentatywne dla środkowoeuropejskiego dworu biskupiego oraz na ile odzwierciedlają jego specyfikę. Czy także np. skąpe wydatki na lutnistów są dowodem na niewielką rolę świeckiej muzyki na dworach przynajmniej niektórych kościelnych hierarchów? I w tym przypadku nie można przeceniać wymowy źródeł rachunkowych, bo nie wiadomo, czy biskupowi towarzyszyli na stałe zatrudnieni muzycy.

Adres Autorki:

dr hab. Ewa Wółkiewicz, prof. IAE PAN

Instytut Archeologii i Etnologii PAN

Al. Solidarności 105, 00-140 Warszawa

ewawolkiewicz@op.pl

https://orcid.org/0000-0002-0604-5694

\section{BIBLIOGRAFIA}

\section{Źródła archiwalne}

APWr [Archiwum Państwowe we Wrocławiu], AmW [Akta miasta Wrocławia], nr 358.

APWr [Archiwum Państwowe we Wrocławiu], DmW [Dokumenty miasta Wrocławia].

APWr [Archiwum Państwowe we Wrocławiu], Rep. 116, nr 309 (zag.) (do sprawdzenia)

AAW [Archiwum Archidiecezjalne we Wrocławiu], II b 2, III d 1a.

AAW, DC [Dokumenty w układzie chronologicznym].

\section{Źródla drukowane i opracowania}

Catalogus. 1887. Catalogus episcoporum Wratislaviensium, [w:] Joannis Dlugossi Opera omnia, t. 1, red. J. Polkowski, Ż. Pauli, Cracoviae, s. 439-447.

Dembińska Maria. 1963. Konsumpcja żywnościowa w Polsce średniowiecznej, Wrocław.

Dola Kazimierz. 1983. Wrocławska kapituła katedralna w XV wieku. Ustrój - sktad osobowy - dziatalność, Lublin.

Dryja Sławomir. 2009. Technologia produkcji słodowniczej i piwowarskiej w średniowieczu i na początku ery nowożytnej w Krakowie, [w:] Wytwórczość w Polsce średniowiecznej i nowożytnej, red. J. Chudziakowa, Archeologia Historica Polona, t. 18, Toruń, s. 185-208.

Dygdała Jerzy. 1997. Wydatki biskupa Adama Stanisława Grabowskiego podczas pobytu w Gdańsku w latach 1737-1738, [w:] Ludzie - kontakty - kultura XVI-XVII wieku. Prace ofiarowane Profesor Marii Boguckiej, red. J. Kowecki, J. Tazbir, Warszawa, s. 111-117.

Fouquet Gerhard. 1988. „, Wie die kuchenspise sin solle“-Essen und Trinken am Hof des Speyerer Bischofs Matthias v. Rammung (1464-1478), „Pfälzer Heimat”, R. 39, s. 12-27.

Hirsch Volker. 2004. Der Hof des Basler Bischofs Johannes von Venningen (1458-1478). Verwaltung und Kommunikation, Wirtschaftsführung und Konsum, Residenzenforschung, t. 16, Stuttgart.

Jujeczka Stanisław. 2006. Duchowieństwo średniowiecznej Legnicy. Studium prozopograficzne nad klerem diecezjalnym, Legnica.

Karbowiak Antoni. 1900. Obiady profesorów Uniwersytetu Jagiellońskiego XVI i XVII wieku, Kraków.

\footnotetext{
${ }^{86}$ Por.: Urban W. 1959, s. 216-236.

87 Catalogus. 1887, s. 474.
} 
Karst Dobiesław. 2002. Technologia rzemieślniczej produkcji piwa we Wrocławiu w okresie średniowiecznym i nowożytnym na tle browarnictwa europejskiego, [w:] Piwo we Wrocławiu od średniowiecza po czasy współczesne, red. H. Okólska, Wrocław, s. 9-45.

Kleinschmidt Wolfgang. 2012. Essen und Trinken in der frühneuzeitlichen Reichsstadt Speyer. Die Rechnungen des Spitals St. Georg (1514-1600), Münsteraner Schriften zur Kulturanthropologie/ Europäischen Ethnologie, t. 17, Münster.

Klonder Andrzej. 1983. Browarnictwo w Prusach Królewskich (2 połowa XVI-XVII w.), Wrocław.

Kochbuch. 1958. Wiswe Hans, Ein mittelniederdeutsches Kochbuch des 15. Jahrhunderts, „Braunschweigisches Jahrbuch", R. 37, s. 19-63.

Kościelak Sławomir. 2012. Spiżarnia biskupa - spiżarnia zakonnika. Spożywcze gusta duchownych z okolic Gdańska na przełomie XVII i XVIII wieku, [w:] Historia naturalna jedzenia. Między antykiem a XIX wiekiem, red. B. Możejko, współprac. E. Barylewska-Szymańska, Gdańsk, s. 252-264.

Kozák Petr. 2016. Meals and beverages on Prince Sigismund's dining table: Some remarks on the possibilities of knowing the diet of the Jagiellonian rulers at the turn of the 15th and 16th centuries, „Perspektywy kultury”, R. 15, s. 61-107.

Kuropatnicki Andrzej K. 2012. Food \& Drink in the Household of English Nobility in the 15th and 16th Centuries. Procurement - Preparation - Service and Consumption, Kraków.

Liber fundationis. 1889. Liber fundationis episcopatus Vratislaviensis, eds. H. Markgraf, J.W. Schulte, Codex Diplomaticus Silesiae, 14, Breslau.

Liber ordinis rerum. 1983. Liber ordinis rerum (Esse - Essencia - Glossar), t. 1: (Einleitung - Text), ed. P. Schmitt, Tübingen.

Łaszewski Witold. 2011. Kilka słów o dworze biskupim przy ul. Najświętszej Marii Panny w Legnicy, „Szkice Legnickie”, R. XXXII, s. 5-28.

Okólska Halina. 2002, Wroctawski cech karczmarzy w okresie od 2 pot. XIII w. do końca XVIII w., [w:] Piwo we Wrocławiu od średniowiecza po czasy współczesne, red. H. Okólska, Wrocław, s. 49-58.

Pudełko Jerzy. 1971. Zagadnienia urbanistyczne średniowiecznej Legnicy w świetle spisu czynszowego z roku 1451. Próba rekonstrukcji parcelacji, „Kwartalnik Architektury i Urbanistyki”, R. 16, s. 249-268.

Rabeler Sven. 2000. „Da fant mein her nit anderst dan kalbfläsch“_-Fleisch und Fisch im Kochbuch des Ulrich Schwarz, [w:] Goldene Speisen in den Maien. Das Kochbuch des Augsburger Zunftbürgermeisters Ulrich Schwarz († 1478), red. G. Fouquet, Siegener Abhandlungen zur Entwicklung der materiellen Kultur, 30, Siegen, s. 110-125.

Samsonowicz Agnieszka. 1991. Łowiectwo w Polsce Piastów i Jagiellonów, Wrocław.

Sperka Jerzy. 2012. Dwór pierwszych Jagiellonów a tajniki średniowiecznej kuchni, [w:] Historia naturalna jedzenia. Między antykiem a XIX wiekiem, red. B. Możejko, współprac. E. Barylewska-Szymańska, Gdańsk, s. 62-69.

Stadtkölnische Reiserechnungen. 2007. Stadtkölnische Reiserechnungen des Mittelalters, ed. K. Militzer, Publikationen der Gesellschaft für Rheinische Geschichtskunde, t. LXXV, Köln.

Strauss Felix. 1987. Die Speiseordnung einer Woche a, erzbischöflichen Hof zu Salzburg aus dem Jahre 1550, [w:] Festschrift Othmar Pickl zum 60. Geburtstag, red. H. Ebner i in., Graz-Wien, s. 589-603.

Urban Wincenty. 1959. Studia nad dziejami wrocławskiej diecezji w pierwszej połowie XV wieku, Wrocław.

Urkundenbuch 1866. Urkundenbuch der Stadt Liegnitz und ihres Weichbildes bis zum Jahre 1455, wyd. F.W. Schirrmacher, Liegnitz.

Witkowski Andrzej, Żerelik Rościsław. 2001. Wykaz ryb Śląka z połowy XIV wieku, [w:] Studia i materiały z dziejów Ślaska i Małopolski, red. R. Żerelik, Wrocław, s. 167-178.

Wółkiewicz Ewa. 2004. Kapituła kolegiacka św. Mikołaja w Otmuchowie. Dzieje — organizacja - sktad osobowy (1386-1477), Opole.

Wółkiewicz Ewa. 2008. Pinguis pastor, oves macre. W kwestii organizacji dworu biskupa wrocławskiego Jodoka z Rožmberka (1456-1467), [w:] Dvory a rezidence ve stredovëku, t. II: Skladba a kultura dvorské spolecnosti, red. D. Dvoracková-Mala, J. Zelenka, Praha, s. 363-385. 
Wółkiewicz Ewa. 2010. Curia episcopalis. Organizacja rezydencji biskupów wrocławskich w późnym średniowieczu, [w:] Dom, majątek, klient, stuga - manifestacja pozycji elit w przestrzeni materialnej i społecznej (XIII-XIX wiek), red. M. Pauk, M. Saczyńska, Warszawa, s. 286-320.

Wółkiewicz Ewa. 2012. Episcopus ambulans. Formy i organizacja podróży biskupów wrocławskich w póżnym średniowieczu, [w:] Samotrzeć, w kompanii czy z orszakiem? Podróżowanie w średniowieczu i w czasach nowożytnych, red. M. Saczyńska, E. Wółkiewicz, Warszawa, s. 83-109.

Wykaz regestów. 1970. Wykaz regestów dokumentów Archiwum Archidiecezjalnego we Wrocławiu, cz. II: Dokumenty w uktadzie chronologicznym, oprac. W. Urban, Warszawa.

Zíbrt Čeněk. 1927. Staročeské umění kuchařské. S pưvodnimi obrázky, Praha.

\section{Bishop's pantry: \\ Consumption at the manor of the bishop of Wrocław in light of accounts from 1449-1450}

This article contains an analysis of accounts from the manor of Legnica, the centre of one of the estates that belonged to the Wrocław bishopric. The estates of the bishopric in Legnica are mentioned as early as 1155 , but the functioning of the bishop's seat there is only confirmed from the mid-13th century. The bishop's manor played an important role in the organisation of tours around the dioceses.

The surviving records contain extensive lists of products supplied for Bishop Piotr Nowak during his five visits to the court in Legnica between June 1449 and the end of April 1450. The bishop was accompanied by an entourage, which during two of his stays in Legnica was made up of over 40 people. The Ordinary's stays were relatively short and did not last longer than five or six days. The total expenses of the estate administrator amounted to about 65 grzywnas (marks), which makes it possible to calculate the cost of purchases per day at about 3 marks. The highest expenses were for the purchase of meat (approx. 37\% of the total) and fish (approx. $17 \%$ ), as well as for the purchase and brewing of beer (approx. 23\%).

The lists presented in this paper do not include all the costs associated with the bishop's visits, which is associated with the very specific nature of the accounting record used for the analysis. In materials of this kind usually only purchases made at the market are recorded, while previously acquired stocks and produce harvested from estate itself are not taken into account. Despite the imperfections of the analysed documents, these records do provide some insight into the dietary habits of the bishop and the functioning of his court.

From the records of the procurator of Legnica emerges a picture of an extraordinary situation and a considerable mobilisation of his scarce staff during these visits. The arrival of such a large group of people required additional purchases of food, tableware, and kitchen equipment, as well as efforts to feed and tend the horses. The accounts show a clear difference between the usual functioning of the manor and the extraordinary period when the bishop visited. What draws the most attention is the exceptional variety of produce and the care taken during each visit to serve delicacies which had not been served to the Bishop during his previous stays. Most of these delicacies were bought in small quantities and were clearly intended only for a small group of people, perhaps even only for Bishop Nowak himself.

Translated by Karolina Płoska

Proofread by Rebecca Gorzynska 